Insgesamt hinterlässt Svetlana Bogens Studie (deren Anmerkungsapparat passagenweise etwas nachlässig gearbeitet ist) einen ambivalenten Eindruck: Das ambitionierte Vorhaben, sich Mandel'štams späten Gedichten im Zeichen des Performativen anzunähern, eröffnet ohne jeden Zweifel eine Vielzahl an Perspektiven, die ein intertextuell ausgerichteter Zugang so nicht zu bieten vermag und die in den Einzelanalysen zum Teil auch eingelöst werden. Dessen ungeachtet hätte eine stringenter gehaltene Darstellung dem gewählten Ansatz wohl ein deutlich höheres Maß an Überzeugungskraft verliehen.

Stefan Simonek

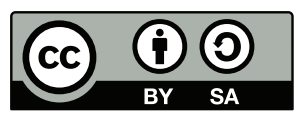

This work can be used in accordance with the Creative Commons BY-SA 4.0 International license terms and conditions (<https://creativecommons.org/licenses/by-sa/4.0/legalcode>). This does not apply to works or elements (such as images or photographs) that are used in the work under a contractual license or exception or limitation to relevant rights.

\title{
K výzkumu etnických stereotypů ve střední Evropě
}

ZELENKA, M. - TKÁČ-ZABÁKOVÁ, L. (eds): Imagológia ako výskum obrazov kultúry: $K$ reflexii etnických stereotypov krajín $V_{4}$. Nitra: Univerzita Konštantína Filozofa, 2018, 162 s. ISBN 978-80-558-1294-6.

Publikace je výstupem z vědecko-výzkumného projektu VEGA 1/0629/17 s názvem „Etnické stereotypy v literatúre krajín $\mathrm{V}_{4}$ “ a je vydávána „pri príležitosti 15. výročia založenia Fakulty stredoeurópskych štúdií Univerzity Konštantína Filozofa v Nitre". Jak čteme už v metodologicky koncipovaném Úvodu, přináší tato kolektivní monografie, na níž se podílelo patnáct badatelů ze zemí $\mathrm{V}_{4}$ (jádrem autorského kolektivu jsou členové špičkového badatelského týmu Stredoeurópske medziliterárne vzt’ahy při FSŠ UKF), „teoretické, literárnohistorické a kulturologické reflexie z oblasti, ktorá je tradične vymedzovaná ako špecifická disciplina porovnávacej literárnej vedy s náležitou metodológiou. “(S. 5.) Imagologie by podle editorů svazku měla být „chápaná ako spôsob medzikultúrnej, hermeneuticky orientovanej komunikácie, v ktorej analýza stereotypov nesmie slúžit $k$ vlastnej prezentácii a interpretácii „cudzieho“, ale $k$ jeho pochopeniu, porozumeniu či nastoleniu dialógu. “(Tamt.) Právě na tomto místě je nutno připomenout další důležitý fakt, nejen pro badatele, ale i studenty literární komparatistiky, že editoři „na záver zborníka pretláčajú slovenský preklad zásadnej štúdie jedného zo 
zakladatelov imagologickej metódy Huga Dyserincka Komparatistická imagológia, ktorú možno považovat za metodologickú propedeutiku v imagologickej oblasti skúmania, a zároveň predpokladajú, že tento inšpiratívny text aj po dlhšom časovom odstupe sa stane čitatel'sky zaujímavý pre bádatel'skú $i$ širšiu verejnost." "(S. 6.) Pro čtenáře publikace je důležité nejen orientační anglické „summary“, ale také uvedení jmenného rejstříku, jenž usnadňuje práci s knihou; ta je psána slovensky, avšak s přehlednými anglickými abstrakty u každé studie.

Jakkoli editoři prezentují monografické studie projektu jako „metodologický stimul podnecujúci rozvíjajúci sa dialóg o charaktere imagologických reflexií, zároveň aj ako konkrétny literárnohistorický príspevok $k$ hlbšiemu poznaniu kultúrnych dejín strednej Európy“, nejde jen o podnět, nýbrž o ucelenou koncepci imagologického studia, kterou pokládáme za nosnou a významnou. Autoři v ní navazují na poměrně bohatou literaturu (její přehled podává Miloš Zelenka) věnovanou výzkumu stereotypů, auto- a hetero-stereotypů, „etnostereotypü“, „archestereotypư “, „obrazü“, „images“, „imagotypů“, mentálních obrazů „vlastního a cizího“ etc.; z nejnovější produkce jmenujme napr. monografii Michaely Voltrové Terminologie, Methodologie und Perspektiven der komparatistischen Imagologie (Berlin: Frank \& Timme, 2015, 195 s. ISBN 978-3-7329-0147-0), Małgorzaty Świderské Theorie und Methode einer literaturwissenschaftlichen Imagologie: dargestellt am Beispiel Russlands im literarischen Werk Heimito von Doderers (Frankfurt am Main: Peter Lang, 2013, 263 s., ISBN 978-3631-63594-0) nebo studie vědecko-výzkumného projektu Etnické stereotypy v historickom výskume (Eds Gabriela Dudeková a Enikö Csukovits. In: Forum Historicae, r. 6, 2012, č. 2, ISSN 1337-6861).

Úvodní literárněvědná studie Miloše Zelenky nazvaná „K teórii komparatistickej imaginológie (úvodné tézy)“ má historicko-metodologický charakter a „načrtáva teoretické základy a historický vývoj imagológie ako komparatívnej disciplíny, ktorá prostredníctvom obrazu „cudzieho" a „vlastného“ skúma obraz „iného“ v literárnych textoch, sústreduje sa najmä na prínos klúčových osobností imagológie (H. Dyserinck, M. F. Guyard, D. H. Pageaux, B. N. Motlaghová, M. Beller, f. Leerssen atd.). “ Autor v ní rozděluje „poslednú etapu imagologického skúmania (od go. rokov 2o. st. do súčasnosti) na literárnovednú líniu a antropologickú analýzu dejín mentalít, ktorá chápe stereotyp ako formu kanonizovaného kultúrneho obrazu určeného prevažne sociologickými východiskami." Připomíná současně, že problémem zůstává „interpretácia vzájomnej súvislosti estetickej hodnoty a národného charakteru obrazu z pohladu jeho etnického vymedzenia.“(S. 7.) V návaznosti na výzkumy D. H. Pageauxe uvádí, že v „imagologickej perspektive texty nečleníme podla estetickej povahy, ale podla ich tematickej závažnosti a najmä podla recepčného dosahu na okruh vnímatelov. "(S. 10.) V této souvislosti je třeba dodat, že (skutečná nebo iluzorní) schopnost autora uměleckého díla přesáhnout ustálený etnický či jiný obraz „vlastního“ a „cizího“ je už sama o sobě chápána 
(literárním historikem nebo kritikem, popř. prezentována literární reklamou) jako element estetické hodnoty artefaktu - je totiž přirozeně spojována s noetickou, poznávací hodnotou literárního díla, které takto (skutečně nebo domněle) „narušuje“ etnické či jiné stereotypy. Závěrem autor dodává, že odideologizované „štúdium dôležitosti a funkcie národných obrazov a stereotypov v procesoch utvárania národov relativizuje nielen vo vedeckom diskurze chápanie národa a jeho jazyka ako objektívne danej, organizovanej taxanomickej jednotky pre štúdium literatúry. Komparatistická imagológia tak nemá význam iba pre porovnávaciu literárnu vedu, ale aj pre iné oblasti, ako politika, sociológia, psychológia." (S. 13-14.) Je tedy zřejmé, že studovaná metodologie má přesah $\mathrm{k}$ mnoha vědním oborům současně.

Studie Tibora Žilky „Etnicita ako prostriedok stereotypizácie (literárnych) postáv“ vychází ze skutečnosti, že „/t/opografické začlenenie postáv sa v literatúre často realizuje prostredníctvom zaužívaných predstáv spojených s pôvodom, národnou identitou a etnicitou. Kontrastný vztah „vlastného" $a$ „cudzieho" tak slúži autorom literárnych textov ako účinný identifikátor postáv“. Předmětem jeho badatelského zájmu „je vymedzit obraz Slováka v mad'arskom literárnom kontexte, resp. mad'arských postáv $v$ slovenskej próze a naopak. “ (S. 17.) Slovenské postavy v madarské literatuře (M. Jókai, I. Madách, K. Mikszáth ad.) autorovi studie vystupují jako dílem reprezentanti nezkaženosti a čistoty lidu, stojícího mimo vliv velkoměsta a technické civilizace, dílem jako humorné, nebo naopak tragické (vytěsněné a marginalizované), dílem pak jako součást manipulované a zmanipulované masy. Ve slovenské próze (P. Jaroš, M. Urban, L. Ballek, A. Hykisch ad.) vystupuje Madar jako postava satirická (např. jako renegát, „Madarón“), nebo jako představitel moci (kruté), také jako podnikatel spojený s městským prostředím (proti slovenskému rurálnímu typu), přičemž Madarka je pak výrazně temperamentní postava, „ktorá erotizuje okolie“. (S. 20.) T. Žilka současně uvádí, jakými prostředky současná postmoderní literatura stereotypy narušuje (Pavol Vilíkovský).

Studie Petra Káši nazvaná „Akí sme my Rusíni?“ načrtává kontury formování kolektivní identity Rusínů ve středoevropském kontextu s jistými analogiemi se slovenským národním hnutím. Zaměřuje se především na analýzu básnických a esejistických textů současného rusínského básníka Štefana Suchého: „Umelecké diela interpretujem ako texty kultúry, v ktorých sú zakódované aj isté obrazy Rusínov, ako aj stereotypy $v$ ich vnímaní v reláciách strednej Európy a krajín V4." (S. 29.) Anna Zelenková ve studii „K imagologickej reflexii toposu drotára v libretách J. K. Chmelenského a K. Želenského (,Obraz suseda 'v česko-slovenských kultúrnych vzt’ahoch 19. storočia) “ autorka analyzuje libreta oper Dráteník a U Božích muk a dospívá k závěru, že „napriek časovému odstupu viac ako pol storočia poukazuje divácka oblúbenost' obidvoch opier na potenciálne konotácie tohto toposu (exotická inakost', sociálne poniženie, typ slovenského vlastenca a pod.), ktoré vyhovovali 
narastajúcej politickej aktualizácii česko-slovenskej vzájomnosti na konci 19. storočia." (S. 37.)

Ivan Halász se v př́spěvku nazvaném „LLudovost" a ,dedinskost“ slovenskej literatúry: stereotyp alebo realita?" zabývá „častým stereotypom o ludovom a dedinskom charaktere slovenskej literatúry v 19. a 20. storočí a snaží sa tento stereotyp relativizovat"“. Podle autora značná část literární produkce 2. poloviny 19. století a začátku století dvacátého „sa tematicky venuje skôr malomestskému a farársko-strednostavovskému prostrediu, z ktorého vzišla väčšina autorov tohto obdobia“ (S. 45.) Stereotyp „ludovo-dedinskej literatúry" byl dle Halásze dále podpořen vznikem Československé republiky, která se snažila „vymedzit voči aristokratickému charakteru Rakúsko-Uhorska“, a tento přežíval i v letech po druhé světové válce.

Zoltán Németh $\mathrm{v}$ analýze nazvané „Deštrukcia etnických stereotypov v stredoeurópskych románoch pod pseudonymom "ukazuje, že různé formy odhalování etnických stereotypů jsou součástí právě postmoderní stylizace a s ní spjatého „znejistěni“ a hry se čtenářskými očekáváními, nejednou také stereotypními, a to na dílech Jana Cempírka (pod pseud. Lan Pham Thi), Danieli Kapitáňové (pseud. Samko Tále) a Alfonze Talamona (pseud. Samuel Borkopf).

Gabriella Petres Csizmadia pojednává v př́spěvku „Skúsenost’ cudzoty v románe Katariny Durica Milovat’ po slovensky" o obrazu madarské identity na Slovensku. Román „Szlovákul szeretni“ „sa zaoberá problematikou Mad’arov žijúcich na Slovensku, pre ktorých sa pojmy vlast', domov, rodisko, národ a materinský jazyk rozmazávajú". Podle autorky právě komplikovanost a vícevrstevnatost identity „Mad'arov na Slovensku vedie $k$ odcudzeniu od ,tých druhých “, vytvářejí se různé sebeobrazy a sebeprezentace. „V texte sa konfrontuje skupina , my' so skupinou , tí druhí a odcudzenie od ,vlastného'vedie k tomu, že ,sa stáva druhým:" (S. 61.)

Ján Gallik ve studii „Formovanie stereotypného pohladu na Židov v slovenskej tlači“ př̀sunuje pozornost na aspekt, který je stejně důležitý jako popis a analýza stereotypů literárních, tedy na genezi stereotypů a reakcí na ně, a to v souvislosti s dobovou publicistikou a romány Martina Rázuse Krčmársky král (1935) a Gejzy Vámoše Odlomená haluz (1934). Připomíná, že umělecká reflexe stereotypů neznamená automaticky negativně vnímanou stereotypnost zobrazení, a současně upozorňuje na další faktory a na to, jak jeden a týž jev, postava jako „obraz etnicity“, byl vnímán ambivalentně, přirozeně jednoznačně negativně jen antisemitskou ideologií: ta na složitost problematiky vždy rezignovala ve prospěch „konečného řešení", v extrémním př́padě i vyhlazení.

Informativní recenze bohužel nemůže představit všechny př́spěvky badatelů, členů řešitelského týmu. Mezi všemi dalšími připomeňme např. Štefana Timka a jeho „Obraz židovskej menšiny v slovenskej kinematografii“, soustředující se na téma holocaustu, tzv. arizace a antisemitské argumentace. Např. o filmové adaptaci Obchodu 
na korze oprávněně soudí, že sice je „pravdou, že Kadár s Klosom vyhrocujú v Obchode na korze konflikt medzi amorálnymi predstavitelmi a prívržencami režimu a jeho relatívne bezbrannými a nevinnými obetami, je však nekorektné tento konflikt vo filme čítat ako spor národnostný - teda spor zlých Slovákov a dobrých Židov (prípadne ich prívržencov). Obe ústredné postavy filmu sú precízne psychologicky vykreslené, postava starej židovky Lautmannovej je vzdialená melodramatickej a sentimentálnej hrdinke. $V$ kontexte rozvíjanej témy dobového prenasledovania je síce obetou nespravodlivého útlaku generujúcou súcit publika, jej plasticky vykreslená postava ponúka i komické momenty, vo vyhrotených situáciách prejavuje aj panovačnost', vzdorovitost' i zlost voči tragikomickej postave arizátora Brtka. Postava Tóna Brtka síce v úvode slubuje divákovi komický archetyp mentálne jednoduchšieho submisivneho smoliara, v tragickom vyústení však odhaluje svoj rozmer nadpriemerne citlivej a ludskej osobnosti." (S. 91.) Židovskou tematikou se zabývá i Magdaléna Hrbáček ve studii „Vybrané židovské stereotypy v strednej Európe“, zaměřující se na negativní i pozitivní stereotypy mj. ve světle karikatur a anekdot. Jak plyne z prezentovaného materiálu, nabízejí zvláště anekdoty ambivalentní texty: na jedné straně stereotypy prezentují, na druhé straně s nimi operují jako s materiálem a látkou, a tak je relativizují, nadsazují a přetvářejí zdaleka nikoli jen $\mathrm{v}$ předsudečném a zlovolném světle. I další přispěvatelé monografie (Hana Guzmická, Tomáš Móri, Simona Mikušková, Dominika Hlavinová Tekeliová, Lenka Tkáč-Zabáková) vnášejí nová a důležitá hlediska pro komplexní výzkum problematiky, jenž nechce být omezen jen na paušalizující charakteristiky.

Kolektivní monografii uzavírá metodologicky zásadní, př́mo „zakladatelská“ studie Huga Dyserincka „Komparatistická imagológia“, reagující na kritiku, podle níž studium recepce a působení literatury povede $\mathrm{k}$ rozpuštění literárněvědné komparatistiky a její specifičnosti v sociologii nebo etnopsychologii. Badatel soudí, že tomuto argumentu „možno ešte dnes čelit dvoma protiargumentami: Človek si môže položit otázku, či je pravda, že imagológia ako taká patrí do oblasti skúmania, ktorá je špecificky „mimoliterárna“. Tiež sa môže opýtat', či je zasahovanie určitých aspektov skúmania obrazu do oblastí, ktoré presahujú hranice literárnej vedy, dostatočným dôvodom nato, aby sa ňou komparatista nezaoberal. Po hlbšej úvahe okamžite vyjde najavo, že odpoved" musí byt’ voboch prípadoch negatívna." (S. 146.) V polemice s René Wellekem dovozuje, že „obrazy“ jsou tak úzce spjaté s obsahem i formou díla, že toto bez nich nelze smysluplně interpretovat. A dovádí príijatá východiska do důsledků, tedy že „skutočné odideologizovanie týchto medzinárodných literárnych súvislostí je možné len vtedy, ked'sa spracujú na multinacionálnej úrovni z hladiska, ktoré nie je viazané ani na germanistické, ani anglistické, romanistické, alebo hocijaké iné národnoliterárne modely myslenia. " (S. 147.) Podle Dyserincka si dokonce komparatistická imagologie neklade za cíl hledat národní zvláštnosti literatury, které literatura nějakou formou zrcadlí, ba ani nepředpokládá, že by mohly „také faktory existovat.“ (S. 149.) 
Vyjadřuje vůbec radikální skepsi „k teóriám národnej svojráznosti“, skepsi, „ktorá je už dnes pre nás samozrejmostou“. Vzhledem k faktu, že celek „národní literatura“ a „národní specifičnost“ je hluboce vnořen do vnímání literárních jevů a má nesporně interpretační povahu, je to stanovisko dnes vyžadující další verifikaci materiálovou, literárněhistorickou: jde o to, zda naše představy „vlastního“ a „cizího“ jsou jen „obrazy“ a „zrcadla“, nebo se zakládají na něčem hlubším, dejme tomu objektivním, z čehož jsou vyvoditelné či alespoň pochopitelné. Dyserinck se neptá, čím je literární celek (jeho podstata či národní specifičnost, dávaje výraz „národ“ do uvozovek, nebot’ „nevychází z předpokladu existence národního charakteru“) „,nemeckej, francúzskej, alebo anglickej literatúry" (vše s. 149), ale které vlastnosti jsou zvenčí těmto literaturám připisovány. Jde mu o uchopení forem projevu obrazů, jejich vzniku a působení.

Přesto se nabízejí četné otázky, na které by další výzkum mohl dát odpovědi, v knize jen naznačené: do jaké míry je možné chápat polysémantické literární jevy (elementární motivy, postavy, symboly, idiomy, ritualizované chování) právě a jednoznačně jako „stereotypní prezentace a re-prezentace mentální reality“? Nehraje v tomto vnímání „obrazu jako stereotypu“ důležitou roli i samotný subjekt vnímajícího, jeho zkušenostní komplex a horizonty očekávání podporované školou, rodinou, médii, subjekt, jehož „Já“ klade obrazy identit „Já“ i „Nejá“ jako reprezentaci - stereotyp? Neukotvuje právě naše interpretace zkušenosti určité obsahy na ose - přijetí/odmítnutí, špatné/dobré, blízké/vzdálené, stereotypní/pravdivé? Do jaké míry je toto vnímání (autora, dobového i dnešního recipienta) „determinováno“ onou realitou samou? Do jaké míry jde o etnický stereotyp a do jaké míry jde o zkušenostní soud, nebo dokonce statisticky verifikovanou a verifikovatelnou skutečnost? Do jaké míry je stereotypní postmoderní „hra se stereotypy“? A má podobné zjištění, pozitivní nebo negativní, nějaký vliv na posuzování estetické hodnoty daného literárního jevu, textu, který je vždy polyvazebný, ambivalentní, naplněný interpretačním neklidem? Další výzkum by se mohl odvíjet právě naznačeným směrem. Ostatně monografie na některé z nich odpovídá, ale nezdá se, že by odpovědi mohly být paušální a jednoduché.

Kniha badatelského kolektivu poskytuje seriózní základ srovnávacího výzkumu etnického obrazu „našeho“ a „cizího“, obrazu nás samých v zrcadle nás samých, tak i obrazů druhého, $v$ tom je její nesporný přínos. Metodologicky přesahuje výzkum stereotypů etnických, jakkoliv právě na ně se soustředí. Lze předpokládat, že představuje i bází pro výzkum jiných stereotypů, nikoli už etnických a kulturních, ale dokonce politických (současný mediální image komunisty jako dábla v kontrastu s oficiálním stereotypem komunisty jako „předobrazu nového člověka“, nebo stereotyp „převrácených“ mužských a ženských rolí v dnešní literatuře, ale i stereotypní prezentace „svobody“ a „totality“ v těch samých mainstreamových mediích, etc. etc.).

Forma, jíž jsou studie psány, umožňuje, aby tyto byly čteny nejen akademickou obcí, ale i studenty - nejen kulturologie, ale i filologických specializací, literární vědy, 
žurnalistiky, politologie, ale i sociologie, pedagogiky etc., tedy aby se monografie stala rovněž užitečnou studijní pomůckou. Je zřejmé, že absolutizace jakékoliv metody, tedy i metody kontrastivně imagologické, by mohla být zneužita $\mathrm{k}$ cílům, před nimiž kniha varuje, tedy k ideologizaci („západní“ kultura je vyšší, protože před stereotypy varuje a odhaluje je, ukazuje tak svoji prevalenci před kulturou „východní, ocitající se v zajetí autostereotypů neschopných sebereflexe), to je však nebezpečí aktuální nejen pro tuto metodologickou oblast a nic neubírá badatelskému týmu na záslužném a užitečném díle. Na díle, které by mělo být přeloženo minimálně do angličtiny, a na záslužném projektu, který by neměl být uzavřen jen jedním výstupem.

Alexej Mikulášek

\section{Literatura:}

ZELENKA, M. - TKÁČ-ZABÁKOVÁ, L. (eds): Imagológia ako výskum obrazov kultúry: $K$ reflexii etnických stereotypov krajín $V_{4}$. Nitra: Univerzita Konštantína Filozofa, 2018, 162 s. ISBN 978-80-558-1294-6.

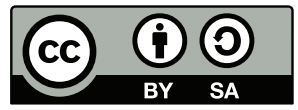

Toto dílo Ize užít v souladu s licenčními podmínkami Creative Commons BY-SA 4.0 International (<https:// creativecommons.org/licenses/by-sa/4.0/legalcode>). Uvedené se nevztahuje na díla či prvky (např. obrazovou či fotografickou dokumentaci), které jsou v díle užity na základě smluvní licence nebo výjimky či omezení príslušných práv.

https://doi.org/10.5817/OS2020-3-10

\section{Творческое путешествие И. Ильфа}

ПОЗДНЯКОВ, К. С.: Возвращение в Одессу. Проза И. А. Ильфа. Самара: АНО «Издательство СНЦ», 2018. 128 с. ISBN 978-5-6042205-2-8.

Современное состояние российского литературоведения и удаленность настоящего времени от эпохи, когда творил И.Ильф, позволили нашему современнику К. С. Позднякову создать увлекательную монографию, в историко-литературном аспекте исследующую творчество данного мастера слова.

Поэтика прозы И. Ильфа анализируется в широком контексте русской и зарубежной литературы: описаны и убедительно охарактеризованы преемственность художественного высказывания названного писателя традициям Н. Гоголя, Ф. Достоевского, Ч. Диккенса, А. Конан Дойла. К. С. Поздняков выявляет творческий диалог И. Ильфа со своими современниками М. Зощенко, 